\title{
Sweeping reforms proposed for securities offerings
}

by Kimberly Anne Summe

\section{$\mathrm{T}$} he US Securities and Exchange Commission (the 'SEC') recently released its long-awaited proposals to modernise the regulatory structure for securities offerings, stating that an effort to respond to dynamic markets and changing capital-raising practices necessitated such action. The proposals, collectively referred to as the 'Aircraft Carrier Release' because of their significant scope (not to mention their nearly 600 pages in length), offer dramatic changes to the current system of securities registration and the disclosure system applicable to public companies. This article will examine seven of the most critical aspects of the proposals and explain how the SEC's reform efforts ultimately result in a complex combination of deregulation and re-regulation.

\section{REGISTRATION FORMS FOR SECURITIES OFFERINGS}

Section 5 of the Securities Act of 1933 (the 'Securities Act') mandates that a public offering of securities requires the filing of a registration statement with the SEC. Congress determined over 60 years ago that requiring companies to disclose certain information would provide investors with material information about the company's securities and would prevent fraudulent practices connected with the offer and sale of securities. The architecture selected for this disclosure system relies on eleven different forms, each one applicable to companies based on factors such as their size, reporting history under the Securities Exchange Act of 1934 (the 'Exchange Act') and whether the company is foreign or non-foreign. The SEC's proposals would eliminate 8 of the 11 forms ( $\mathrm{S}-1, \mathrm{~S}-2, \mathrm{~S}-3, \mathrm{~S}-4, \mathrm{~F}-1, \mathrm{~F}-2, \mathrm{~F}-3$ and $\mathrm{F}-4$ ) and replace them with an entirely new set of three forms: Forms A, B and C.

Form A will be used in securities offerings by smaller or unseasoned companies and will include initial public offerings. Form B will apply to larger, seasoned companies and to offerings to sophisticated investors. Form $\mathrm{C}$ is intended to be used for business combination transactions and will not be discussed in this article.

\section{Form $A$}

The proposed Form A does not contain many significant differences from the forms that it replaces $(\mathrm{S}-1$ and $\mathrm{F}-1)$ as most of the same transactional information is required under the new form. The smaller company's qualification as 'seasoned', however, will allow it to incorporate by reference prior Exchange Act filings. 'Seasoned' is defined for purposes of Form A to mean an issuer with at least a two year Exchange Act reporting history and either:

- a public float of at least $\$ 75 \mathrm{~m}$; or

- at least two annual reports on file.

Importantly, certain seasoned issuers could choose the date their registration statement becomes effective (the date on which securities may be sold). This is a striking departure from the current system that requires SEC review of the registration statement and notification of the company as to when its securities registration is effective. Unseasoned issuers, however, would still be subject to SEC review before their offering becomes effective.

\section{Form B}

Form B would replace Forms S-3 and F-3 and would be available for large, seasoned companies. For purposes of new Form B, a 'large' issuer has either:

- a public float of $\$ 75$ million and an average US daily trading volume ('ADTV') of at least $\$ 1$ million; or

- a public float of $\$ 250$ million.

A 'seasoned' issuer has at least a one-year Exchange Act reporting history, including the filing of at least one annual report. The proposed public float and ADTV requirements constitute a noticeable increase from the current public float threshold for registration under Forms $\mathrm{S}-3$ and F-3. This particular proposal would likely mean that fewer medium-sized foreign private issuers could use Form $\mathrm{B}$, because the $\$ 1$ million ADTV requirement is measured by US trading volume. The SEC estimates that out of the issuers using Forms $\mathrm{S}-3$ and $\mathrm{F}-3$ in 1997, only $70 \%$ would be eligible to use the new Form B.

It should be noted that offerings made solely to qualified institutional buyers, as well as offerings to certain existing security holders (e.g., rights offerings, exercises of outstanding options, etc.) and market-making transactions by broker-dealers affiliated with the issuer, are eligible for Form B. Also, under the proposals the SEC would not review Form B offerings prior to effectiveness - the opposite of the current approach.

\section{COMMUNICATIONS WITH INVESTORS}

Changes are proposed under the following circumstances.

\section{Prior to filing a registration statement}

Section 5 of the Securities Act restricts communications by or on behalf of an issuer, prohibiting oral or written offers of securities prior to the time a registration statement is filed with the SEC. The SEC proposes a significant relaxation of these restrictions, linking the degree of relaxation to the qualifications of the issuer and the offering.

For Form A offerings, the SEC proposals allow communications to be made more than 30 days before the registration statement is filed, without any violation of the terms of s. 5. However, the issuer, participating underwriters and broker-dealers would have to take reasonable steps to prevent further distribution of such communication during the 30 days before the registration statement is filed. For example, the SEC states that an issuer's Internet website may contain information 
on the offering during the free communications period, but such information must be removed by the 30 th day before filing a registration statement. The SEC also states that a press release made 40 days before registration is permissible, but reasonable steps must be taken to ensure that such information is not contained in a news article within the 30-day period before registration.

For Form B offerings, the SEC proposes that communications made more than 15 days before the 'first offer' do not constitute an offer for purposes of s. 5 .

The SEC also proposes a safe harbour from s. 5 for factual business communications made during the 30-day period before a registration statement is filed, regardless of whether a Form A or Form B offering is involved. The proposed Rule 169 includes among the protected communications:

(a) factual information about the issuer or an aspect of its business;

(b) advertisement of the issuer's products or scrvices;

(c) factual business or financial developments with respect to the issuer; and

(d) dividend notices.

Forward-looking information or information about the registered offering is specifically not protected by this safe harbour.

Forward-looking information could be distributed at any time in a Form B offering, but would be required to be filed with the SEC as 'free writing' and therefore subject to liability. For Form A offerings, forward-looking information could be disseminated in the 30-day period before filing the registration statement if the issuer is an Exchange Act reporting issuer that has 'customarily released this type of information in its ordinary course of business for the last two fiscal years'. Forward-looking information that would be covered by this safe harbour includes:

(a) projections of the issuer's revenues, income (loss), earnings (loss) per share, capital expenditures, etc.;

(b) statements about the issuer's plans and objectives for future operations; and

(c) statements about the issuer's future economic performance.

The SEC states that its purpose is to encourage the disclosure of forward-looking information to investors, analysts and others in the securities community, but that it desires to restrict such information to that which is regularly released by the issuer and not to protect information simply released to 'hype' the securities in a particular offering.

\section{After filing but before effectiveness}

Once a registration statement is on file with the SEC, written offers can then only be made through a prospectus whose contents are regulated by s. 10 of the Securities Act. The SEC proposes that issuers could make offers and distribute offering information during the 'waiting period' (after filing but before effectiveness), provided the issuer:

(a) in Form A offerings, delivers the traditional preliminary prospectus to investors either seven calendar days prior to pricing (if a firm commitment, best efforts or initial public offering) or three calendar days before pricing in all other cases; or

(b) in Form B offerings, delivers term sheets to investors and includes information about the selling security holders, if any, including any material relationships with the issuer, and discloses the identity and location of persons to whom questions may be directed.

Such information must be filed with the SEC and must contain a prominent legend advising investors to read the other disclosure documents filed with the SEC before making an investment decision.

The SEC states that it hopes the proposals will enable issuers and market participants to take greater advantage of electronic media and the Internet. For example, investor queries could be addressed on the Internet, 'chat room' discussions with potential investors could be arranged and electronic roadshows could be presented to institutional and retail investors. For Form B offerings, the Internet and electronic media could be used for these purposes both before and after filing a registration statement.

\section{RESEARCH REPORTS}

Research analysts are an important component in the dissemination of information to the marketplace. Currently, three safe harbours exist for the publication of analysts' reports - Rule 137, s. 5. The SEC recognises that these regulations often result in the suspension of research publication around the time of an offering and thus proposes the expansion of these safe harbours, reflecting the view that the increased flow of information to the market is beneficial for investors.

Rule 137 currently protects research published by a brokerdealer not participating in a distribution of the issuer's securities. The proposal modifies this safe harbour to extend its protections to reports on non-reporting companies. Moreover, the publication need not be issued in the broker-dealer's 'regular course of business'. Thus, a broker-dealer could publish reports on a private company planning to make a registered offering, even if the broker-dealer had never published a report before.

Rule 138 allows a broker-dealer participating in a distribution of one type of an issuer's securities to publish research on another type of the issuer's securities. Based on the SEC's proposals for a new registration system, this safe harbour would prove unnecessary except for reports published within the 30-day period before filing a registration statement, in the case of Form A offerings. The proposal would add a requirement that the research prominently describe the capacity in which the broker-dealer is participating in the particular offering.

Rule 139 addresses research about an issuer's class of securities where the publishing broker-dealer participates in that distribution. As with Rule 138, the safe harbour would prove unnecessary except for reports published within the 30-day period before filing a registration statement in the case of Form A offerings. Rule 139 would continue to divide reports into two types:

(a) industry-related reports (reports on a substantial number of companies where the information on the issuer is given 
no greater prominence than the information on other companies); and

(b) focused reports (reports focused on the issuer and its securities).

For industry-related reports, Rule 139 would be modified to expand its availability to reports on any issuer, regardless of its size or reporting history. The proposed modification would also allow reports to include recommendations more favourable than last published if the previous two recommendations published by a then non-participating broker-dealer are disclosed. Focused reports, under the proposal, would eliminate the requirement that the report be distributed with reasonable regularity (the report would still have to be distributed in the broker-dealer's ordinary course of business). In addition, minimum float requirements would be eliminated, so that reports could be published on seasoned reporting issuers, larger, non-reporting foreign private issuers and large offerings by foreign governments, even if the broker-dealer has not previously published reports on the issuer.

\section{DELIVERY OF THE FINAL PROSPECTUS TO INVESTORS}

Section 5 of the Securities Act requires that a final prospectus be delivered to investors prior to or at the time of confirmation of sale. The SEC proposes to exempt most issuers from the final prospectus delivery requirement if a preliminary prospectus has already been delivered (this exemption does not apply in Form $\mathrm{C}$ offerings). However, final prospectuses would still be required to be filed with the $\mathrm{SEC}$.

\section{INCREASED REPORTING DUTIES}

Concern about the uneven flow of information among the investing community led the SEC to propose enhancements to the reporting system mandated by the Exchange Act. The SEC proposes to accelerate the required Exchange Act reporting of certain information, stating that it plans to shift more of its staff resources to the review of such disclosure. Some of these proposed modifications to the Exchange Act reporting system are discussed below.

\section{Annual and quarterly reports: risk factor disclosure}

Currently, most registration statements filed under the Securities Act require an analysis of the risks associated with the particular securitics offering by the issuer. The SEC proposes to expand this analysis to Exchange Act reports, so that risk factor disclosure, presented pursuant to the SEC's recent 'plain English' requirements, will be required in all issuers' annual and quarterly reports. Thus, annual reports (filed on Forms $10-\mathrm{K}$ and 20-F) would be mandated to describe the most significant risk factors with respect to the issuer's business, operations, industry or financial position that could have a negative effect on its future financial performance. Foreign government issuers would be required to describe the most significant risk factors with respect to its financial position and the most significant country risks. Domestic issuers' quarterly reports (filed on Form 10-Q) would be required to disclose all such factors that either:

(a) were not included in their most recent Securities Act registration statement or Exchange Act periodic report, whichever is later; or

(b) had changed since the date of that most recent statement or report. Foreign private issuers would be required to update their risk factor disclosure only on an annual basis (unless such issuer opted to do so more frequently.

\section{Form 8-K: publicly-released financial information}

The SEC proposes that selected financial information would be required to be reported on the earlier of the date the company issues a press release containing earnings information or either the date that is 60 days after the end of their fiscal year (rather than the current 90 days) or 30 days after the end of each of their first three quarters (rather than the current 45 days).

\section{Form 8-K: new reporting items}

The required disclosures reporting companies must make on Form $8-\mathrm{K}$ would be expanded under the SEC's proposals. In addition, the reporting dates would be accelerated. Some of the proposed new reporting disclosures and their due dates are:

(a) material modifications to the rights of security holders reported in five calendar days;

(b) the departure of a $\mathrm{CEO}, \mathrm{CFO}, \mathrm{COO}$ and president reported in one business day;

(c) material defaults on senior securities reported in one business day (unless such default occurs on a federal holiday or weekend, in which case two business days); and

(d) company name changes reported in five calendar days.

Current reporting due dates would also be accelerated. For example, changes in the control of the registrant, its acquisition or disposition of assets or its bankruptcy or receivership status must be reported in five calendar days, rather than the current 15 calendar days. The resignation of any of the registrant's directors must be reported in five calendar days, rather than the current five business days.

\section{Management and director certifications}

The SEC, concerned about board members signing blank signature pages without first reading the relevant disclosure documents, proposes modifications to the signatures section of all registration statements and Exchange Act periodic reports (addressing Forms 8-A, 10, 20-F, 40-F and 10-Q, among others). Under the proposal, the individuals required to sign such documents must certify that they have read the document and that:

.. they know of no untrue statement of a material fact or omission of a material fact necessary in order to make the statements made. not misleading.'

Moreover, the SEC proposes to increase the number of individuals required to sign the above forms, so that the signatories include the principal executive officers and a majority of the board of directors.

\section{Filing deadlines for foreign private issuers}

The SEC proposes to shorten the filing deadline for foreign private issuers' annual reports on Form 20-F to five months from the current six months after the end of the fiscal year. 


\section{GUIDANCE ON UNDERWRITER DUE DILIGENCE}

The SEC states clearly that its reform efforts, as outlined above, do not include any correspondent lessening of liability for issuers, underwriters and broker-dealers. Thus, the general liability principles of the Securities Act are not modified in any fashion under the SEC proposals. One of these key principles is set forth in s. 11 of the Securities Act. This section provides that an underwriter is not liable as to the non-expertise portions of a registration statement if, after reasonable investigation, it had reasonable grounds to believe, and did believe, that the statements were:

true and that there was no omission to state a material fact required to be stated therein or necessary to make the statements therein not misleading ...'

The SEC elaborated on this provision in 1982 when it adopted Rule 176 to provide guidance to courts on the circumstances in which a person's conduct satisfies the due diligence standard of s. 11 .

The SEC acknowledges that its proposed reforms may impose greater timing pressures on underwriters in the execution of their due diligence duties. Thus, several changes to Rule 176 offer underwriters and the courts guidance on the circumstances in which liability would or would not attach (although the absence of one or more factors is not definitive). The proposal identifies six due diligence practices that the SEC believes would 'enhance an underwriter's due diligence investigation'. However, the following six guidelines apply only in cases of a Form B offering of equity or non-investment grade debt securities that were marketed and completed in less than five days. The six guidelines are:

(a) whether the underwriter reviewed the registration statement and conducted a reasonable inquiry into any 'red flag' issues;

(b) whether the underwriter discussed the registration statement with the relevant executive officer(s) and obtained a certification from those officers regarding its accuracy;

(c) whether the underwriter received a comfort letter from the issuer's auditors;

(d) whether the underwriter received a favourable opinion on the registration statement from issuer's counsel;

(e) whether the underwriters engaged their counsel in the review of the issuer's charter, by-laws, minutes and material contracts and received from such counsel a favourable opinion on the registration statement; and

(f) whether a research analyst was consulted who has followed the issuer or its industry for at least six months and has issued a report on the issuer or its industry within 12 months before commencement of the offering.

\section{INTEGRATION OF PRIVATE AND PUBLIC OFFERINGS}

Under the current regulatory system, issuers are considerably slowed in their ability to switch from a private offering to a public offering of securities or vice versa, as a result 'of concerns that a private offering could constitute a prohibited offer in advance of registration, or that filing a registration statement in a public offering could qualify as a 'general solicitation', thereby making a private offering unavailable. The SEC proposals would greatly increase an issuer's flexibility to shift between private and public offerings, provided that critical investor protections are maintained.

\section{Private to public offering}

The SEC proposes that where an issuer has commenced a private offering of securities, but has not yet sold any of these securities, it may abandon the private offering and file a registration statement. The issuer may file the registration statement as soon as it opts for a public offering, provided that it has not offered the securities to persons that would not have been eligible to purchase in a private offering. If the issuer has offered its securities to such an ineligible person, it must wait 30 days after abandoning the private offering to file a registration statement. However, a waiting period is not required in Form B offerings.

\section{Public to private offering}

If an issuer has filed a registration statement for a public offering of its securities, but has not yet sold any of these securities, it may. withdraw its registration statement and either wait 30 days to sell the securities privately or immediately sell the securities privately but accept a higher standard of liability for the written disclosure already provided to purchasers.

\section{SURVEYING THE 'AIRCRAFT CARRIER'}

The SEC proposals offer several significant and welcomed reforms of the securities offering system. Among those beneficial reforms are the SEC's establishment of several communications 'bright lines', allowing issuers and underwriters enhanced communications, with potential investors. Such modifications make sense in a market of increasing electronic communication of information. In particular, loosening the restraints on the publication of research reports will allow more information to reach investors. Additionally, the SEC's proposal to scrap review of a large seasoned issuer's registration statement before making such filing effective will add a welcomed measure of efficiency into the marketplace. Lastly, the increased scope of information required to be reported under the Exchange Act, as well as the acceleration of such disclosure, will benefit individuals involved in secondary trading, affording them access to the same information previously available only to purchasers in the offering.

These beneficial reforms, though, come at a price - a sort of re-regulation for the deregulation. Of great significance to issuers and underwriters is the expansion of strict Securities Act liability to Exchange Act reports. For example, currently an issuer's Exchange Act reports may be incorporated in a prospectus supplement in the case of a shelf offering, but are generally viewed by practitioners as not being part of the registration statement and thus not subject to s. 11 liability (although the SEC's proposal states a contrary view). Under the proposals, such reports must be filed before any sale of a security, bringing such statements under s. 11 standards. 
Section 11 affords no defence to issuers for these statements and provides underwriters with established due diligence considerations.

Another negative aspect of the SEC's proposals is its approach to shelf offerings, which typically involve debt securities. By not allowing Form B to be used in shelf offerings, a significant portion of the securities market will be slowed considerably in its offering of such securities as compared with equity offerings using Form B. According to the SEC, approximately 30\% of issuers currently eligible to use Form $\mathrm{S}-3$ (and thus able to use a shelf registration) would not be able to use Form B (unless such offerings are made only to qualified institutional buyers, or 'QIBs').

Much criticism has also becn directed at the SEC's proposed elimination of Exxon Capital transactions. Exxon Capital is a line of SEC no-action letters that allows Rule 144A offerings to QIBs to be followed by a registered exchange offer of identical securities. Domestic issuers typically use Exxon Capital for highyield debt securities. Foreign issuers use Exxon Capital in cases of an initial public offering made outside the US followed by a registered exchange offer to US QIBs. By eliminating Exxon Capital (and therefore frec marketability), issuers would be forced to register the initial offering. This would incur a greater cost for raising capital, especially for Form A issuers who must seek other forms of financing while waiting for SEC review of their filing.

The SEC requested that comments on its proposals be submitted by 5 April 1999. Interestingly, the SEC stated that its proposals were presented on a more tentative basis than in a typical release. Given that substantial public comment will be offered to the SEC in order to redress some of the problematic reforms mentioned above, it is likely that some of these proposals will be modified, perhaps dramatically. In any event, the proposals will not be implemented until after 31 March 2000 , in order to decrease the possibility of Year 2000 problems.

Kimberly Anne Summe

Investment Banking Legal Division, Morgan Stanley Dean Witter, New York

\section{Ireland}

\section{New protection and its limits under the Investor Compensation Act 1998 by Blanaid Clarke}

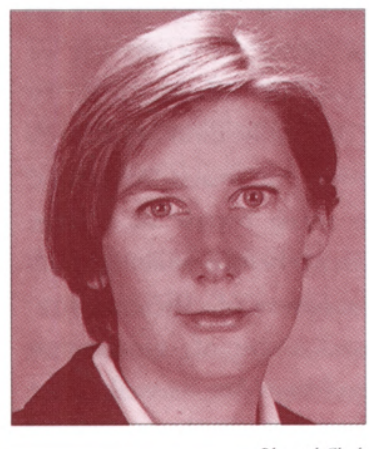

Blanaid Clark $s$ a result of the recent collapse of MMI, a Dublin stockbroking firm with estimated debts of $£ 14 \mathrm{~m}$, the issue of investor compensation has become a particularly pertinent one in Ireland. This is the first collapse of an authorised investment business firm in Ireland since the introduction of the Investor Compensation Act 1998 last July. Clients owed money by MMI can, at least, be reassured by the fact that they should not be affected by the provisional liquidation, once it is established that their funds are in order. Prior to the introduction of the Investor Compensation Act 1998, a number of financial scandals had occurred, culminating in the collapse of the Taylor Group of investment companies in August 1996, with losses of almost $£ 2.5 \mathrm{~m}$ to investors. These investors have little chance of recovering their losses. Whilst legislation had been introduced the previous year providing for the authorisation and supervision of investment firms, additional measures were clearly required.

The idea of an EU investor compensation scheme has its genesis in the Investment Services Directive 93/22/EEC ('the ISD') which provided for the mutual recognition of authorisation and of prudential supervision systems, making possible the grant of a single authorisation valid throughout the EU and the application of the principle of home member state supervision. The ISD was implemented into Irish law in relation to stock exchange member firms by the Stock Exchange Act 1995 and in relation to other investment business firms, by the Investment Intermediaries Act 1995 ('the 1995 Act'). With the advent of a harmonised financial market, it became increasingly important to ensure that each member state should provide an investor compensation scheme guaranteeing a harmonised minimum level to investor protection. The Investor Compensation Schemes Directive 97/9/EC ('the directive') was subsequently introduced requiring member states to ensure that schemes are in place to provide a minimum level of compensation to investors, in the event of the failure of an investment firm in circumstances where the firm proves unable to refund to investors the money or securities belonging to then.

The directive was implemented into Irish law by the Investor Compensation Act 1998 ('the Act') which provides for compensation for clients of investment and insurance intermediaries where the firms themselves are unable to return money or investment instruments belonging to clients. Although the directive merely requires schemes to be in place for firms authorised in accordance with the ISD or, alternatively, in 